slope in the curves. Nevertheless, the method, which had previously been applied extensively and successfully to the location of salt-domes in Texas, proved of value in Persia also, the limestone depths being measured to an accuracy of 10 to 15 per cent. There are, therefore, good grounds for confidence that the surveys being carried out by the Geo-

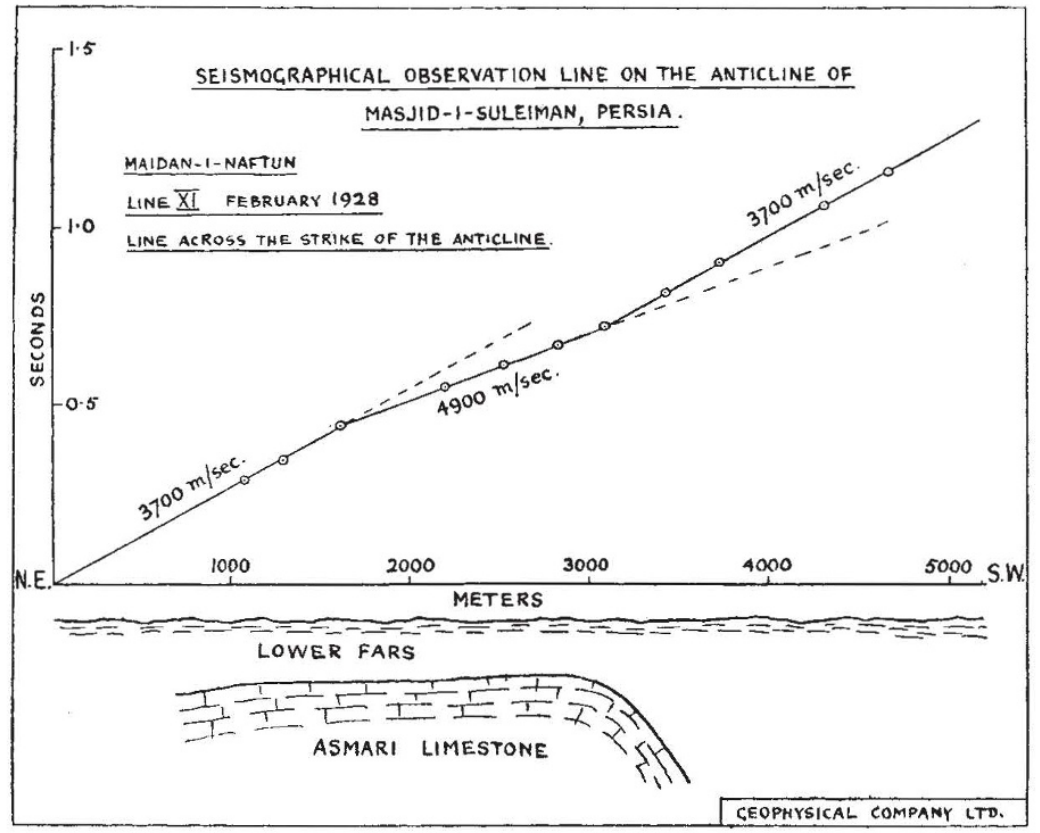

FIG. 6.

physical Company, Ltd., on similar structures of unknown shape in other regions of Persia and in Iraq will provide the data required for successful drilling for oil.

For descriptions of portable seismographs the reader must be referred elsewhere, for example to the recently published translation of Dr. Ambronn's book ${ }^{2}$ which contains the original references.

2 " Elements of Geophysics." By Dr. Richard Ambronn, translated by Margaret C. Cobb. (London: MeGraw-Hill Publishing Co., Ltd.)
Mintrop's seismograph, with which most of the seismic surveying has been done, is one in which the magnification of the earth's movement is secured partly mechanically and partly optically. There are others of the same type, notably Schweydar's, which records also horizontal movements. Another type employs electrical magnification, as in Dowling's and Ambronn's instruments. It is doubtful whether any of them imitates precisely the movements of the earth's surface, but so long as it is merely a question of determining the instant of first arrival of the disturbance, this is of no great importance. It is nevertheless worthy of note that the production of an exact recorder will open new lines of attack on the problem, such as the determination of the angles at which the disturbances arrive at the earth's surface.

Progress is being made in the gravimetric and seismic methods of survey, both as regards improvements of the instruments themselves and the technique of procedure in the field and in interpretation. In this matter Great Britain is much behind-hand; and it is hoped that this artiole may contribute to the stimulation of that interest which is essential to progress.

I desire to express my thanks to the AngloPersian Oil Company, Ltd., and to the Geophysical Company, Ltd., for approving and facilitating the publication of this article. I am specially indebted in this respect to Prof. Mintrop, and to $\mathrm{Mr}$. Ernest H. Neville and Dr. Schmidt of the latter Company.

\title{
The Centenaries of Davy and Young.
}

$\mathrm{I}^{\mathrm{N}}$ $\mathrm{N}$ the National Portrait Gallery hangs the wellknown composite portrait group of eminent British men of science who were alive in 1807-8, the group being shown assembled in the Library of the Royal Institution. There are forty-eight portraits in all, including those of Banks, Watt, Rumford, Jenner, Herschel, Cavendish, Telford, Trevithick, Wollaston, Dalton, Davy, and Young. The oldest represented in the group was Matthew Boulton, the partner of Watt, who was born in 1728, while the youngest was Davy, born just fifty years later, in December 1778.

No more appropriate setting could have been found at that time for such a group, for though at its birth the Royal Institution had for its sponsors many notable men of the day, its infancy had been a somewhat precarious one, and it was mainly through the talents of Davy, then probably at the height of his powers, that it had been rescued from the uncertainties which had threatened its very existence. It had been raised to a foremost position among scientific institutions, where not only the learned, but also the fashionable and the great, gathered to see the striking experiments of Davy and to listen to his brilliant discourses from which we are told Coleridge increased his stock of metaphors.

Founded in 1799 through the exertions of Rumford, the Royal Institution had already counted among its first professors Garnett and Young, but it was the lectures of Davy which marked the beginning of the popularity it has since enjoyed and the reign of discovery with which its name is linked. After Davy came Brande, Faraday, Tyndall, Dewar, and others, and in "Britain's Heritage of Science" we are told "there is no 
building in the world associated with so many classical and revolutionising researches as that in which the Royal Institution is housed".

If the setting for this remarkable group invites our approbation, no less does the date of its execution appeal to our sense of historic fitness. The early years of the still young century had been full of promise, and though owing to the ambition of Napoleon few nations were free from the threat of war, scientific and industrial development was proceeding apace, and the very names of Cavendish, of Herschel, of Watt and of Trevithick recall the pioneering work and the planting of the seed from which our later harvests have come. At home and abroad, science in 1807 was engaging some of the keenest minds. The guillotine, it is true, had robbed France of her greatest chemist, but she still counted among her veterans, Laplace and Lagrange, Legendre and Coulomb, while following in their footsteps came Fourier, Biot, Ampère, Malus, Arago, and Fresnel.

As in France, so in Europe generally, science and invention were bearing good fruit. Astronomy had been enriched by the discovery of Ceres, Pallas, Juno, and Vesta; Volta's great invention of the electric battery was being applied in a hundred experiments; Chladni had made the world his debtor by the publication of his work on acoustics, while Oersted had begun his work at Copenhagen, where he was destined to make his great discovery of electro-magnetism. To the particular years 1807 and 1808 belong the publication by Thomson of the atomic theory of Dalton, the publication of Young's "Lectures on Natural Philosophy", and the memorable experiments of Davy leading to the isolation of sodium and potassium.

However interesting a review of the science of that time may be, our immediate attention is naturally directed to the careers of Davy and Young, both of whom died in May 1829, a hundred years ago, Young passing away on May 10 and Davy on May 29; Young being then but fifty-five and Davy only fifty years of age. Strangely unlike in temperament, in character, and in their reaction to the buffets and rewards of life, they yet present many interesting parallels as well as contrasts. Even Galton would, perhaps, have found it hard to determine the influence of heredity on their careers ; for Davy was but the son of a woodcarver of Cornwall, and Young the son of a Quaker landowner of Somerset. In neither instance, also, did early training have much to do with their subsequent successes. The astonishing precocity of Young was equal to that of a Macaulay or a Rowan Hamilton, and as a boy of fourteen years of age he was acquainted with Latin, Greek, French, Italian, Hebrew, Persian, and Arabic. Davy had a mind equally alert and a memory equally tenacious, but he enjoyed fewer advantages than Young, and it was to a Quaker saddler friend and a self-appointed guardian that he owed the encouragement and assistance without which, perhaps, his genius might have led him to less congenial pursuits. Young was the senior of Davy by five years, and while Davy was serving his apprenticeship to the Penzance apothe- cary and surgeon, Borlase, Young was leisurely following his academic course in medicine at Edinburgh, Göttingen, and Cambridge, where his learning led to his being known as "Phenomenon Young".

It was in 1801 that the paths of these two extraordinary men met, the older one becoming the professor of natural philosophy and the younger the professor of chemistry in the newly founded Royal Institution. Davy's first lecture was given on April 25, 1801, Young's first lecture on Jan. 20, 1802 ; but whereas we are told Young found "the number of his attendants diminish daily, and for no other reason than that he adopted too severe and didactic a style", Davy filled the theatre to overflowing, where " his youth, his simplicity, his natural eloquence, his chemical knowledge, his happy illustrations and well-conducted experiments excited universal attention and unbounded applause".

Of the details of the work of these illustrious investigators many accounts have been given. His experiments with nitrous oxide, his isolation of sodium and potassium and other elements, and his invention of the miner's safety lamp are but a few of the outstanding achievements of Davy, whose name was as familiar in France and Italy as it was in England. His invention of the safety lamp he made a free gift of to mankind, and the silver plate presented to him by the colliery owners in recognition of his work was long since sold and used for founding the Davy Medal of the Royal Society. Young's work illustrates the versatility of his rare mind. His most notable contributions to science were concerned with optics, the strength of materials, and elasticity. The first definitions of ' energy' as we understand it and of 'Young's modulus' are to be found in his "Lectures". His views and discoveries in light were fundamental, and he has been called "the founder of physiological optics". Of Young, Helmholtz said: "He was one of the most clear-sighted of men who ever lived, but he had the misfortune to be too greatly superior in sagacity to his contemporaries. They gazed at him in astonishment, but could not always follow the bold flights of his intellect."

Known widely for their writings, their lectures, their researches, and discoveries, Young and Davy are also remembered for the work they did in connexion with societies, committees, and institutions. Both were foreign associates of the Paris Academy of Sciences, both held secretaryships of the Royal Society, of which Davy was the twenty-fourth president, while Young was long physician to St. George's Hospital. The grave of Young is at Farnborough, Kent; that of Davy in a cemetery outside the city of Geneva. There is a statue of Davy at Penzance, a marble bust of Young in the Shire Hall, Taunton, while each is commemorated by a memorial tablet on the walls of St. Andrew's Chapel, Westminster Abbey. Such memorials, however, may crumble and perish, but the work of Young and Davy will endure for ever ; for as Davy said when presenting the Copley Medal to Arago: "Science, like Nature, to which it belongs, is neither limited by time or space. It belongs to the world, and is of no country and no age." 